\title{
COMPLETING THE CONSTRUCTION MANAGEMENT AT HOA BINH CONSTRUCTION GROUP
}

\author{
Tuan Anh Nguyen ${ }^{*}{ }^{\star}$, Toan Long Pham ${ }^{2}$ 四 \\ ${ }^{* 1}$ Ho Chi Minh City University of Transport, Ho Chi Minh City, Viet Nam \\ 2 Hoa Binh Construction Group, Viet Nam
}

DOI: https://doi.org/10.29121/ijetmr.v8.i2.2021.859

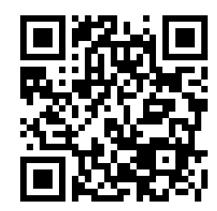

Article Citation: Tuan Anh Nguyen, and Toan Long Pham. (2021). COMPLETING THE CONSTRUCTION MANAGEMENT AT HOA BINH CONSTRUCTION GROUP. International Journal of Engineering Technologies and Management Research, 8(2), 9-20. https://doi.org/10.29121/ijetmr.v8 i2.2021.859

Published Date: 10 February 2021

Keywords:

Management

Quality

Projects

Models

Solutions

\section{ABSTRACT}

The construction industry is one of the major economic sectors. The construction industry's products play an essential role in economic growth, promote the development of science and technology, improve the material and spiritual life for people, affecting the cultural-artistic - architectural development and ecological environment. In particular, the field of infrastructure design and construction is even more indispensable in constructing the country. Today, the market mechanism requires businesses that want to survive and develop to find all measures to increase their competitiveness, conduct production and business with minimal cost, and ensure the work's quality.

\section{INTRODUCTION}

\subsection{CONSTRUCTION MANAGEMENT CONCEPT}

Construction management is an activity in a chain of general construction production and business management activities and is also the most critical activity affecting final construction product's value. Construction management is a set of activities from which requirements, regulations and are implemented by measures such as managing each item in the work of construction organization, control and assurance - quality assurance within a system. Construction management activities are mainly the supervision and self-supervision of the investor and other subjects [1].

\subsection{ROLE OF CONSTRUCTION MANAGEMENT}

Construction management of construction works plays an excellent role for contractors, investors and construction businesses in general. That role is explicitly shown as: 
For contractors (or companies providing construction services), construction management will save materials, labour costs, machinery and equipment, increase labour productivity and especially promote contractors to apply modern science and technology to the construction works.

For investors, construction management will satisfy technical requirements for construction work, save capital, and improve the quality of life of people. If construction management is done near, it will help build investor confidence with the contractor, contributing to a long-term relationship and cooperation[3].

Every year, the investment capital for construction is quite large, accounting for $20-25 \%$ of GDP, so construction management needs to be paid attention. Many construction works are not strictly managed in the past, causing a lot of loss and waste, affecting the quality of construction products and affecting people's lives. Therefore, the urgent issue posed to all construction businesses is how to strictly and effectively manage the construction works.

Construction machinery and equipment are the most essential and vital part of an enterprise's fixed assets. It is a measure of the technical level of the existing production capacity, an essential factor contributing to construction businesses' competitiveness.

Equipment management criteria:

Equipment efficiency $(\mathrm{HM}): \mathrm{HM}=\left(\mathrm{T}_{\mathrm{TT}} / \mathrm{T}_{\mathrm{KT}}\right) * 100 \%$

In which: $\mathrm{T}_{\mathrm{TT}}$ is the actual time of using machinery and equipment on site.

$\mathrm{T}_{\mathrm{KT}}$ is the maximum time to use machinery and equipment within the proper technical scope.

This indicator reflects the efficiency of the use of machinery and equipment in the construction process to ensure construction work quality and progress.

$75 \% £ \mathrm{H}_{\mathrm{M}} £ 100 \%$ : The management of machinery and equipment is effective.

$\mathrm{H}_{\mathrm{M}}<75 \%$ : The management of machinery and equipment is ineffective. Required plan to arrange rational use of machinery and equipment based on improving efficiency use construction machines.

Labour management in production and business plays a significant role because human is the subject of the production and business process; all production and business processes are conducted through human workers with specific economic, political and social qualifications.

The content of human resource management includes master content the following weaknesses:

- Labor organization

- Norms of labour use, labour productivity

The supply of materials in construction production and business plays a vital role because the cost of construction materials usually accounts for $60 \%$ to $70 \%$ of the total cost for construction and installation. The main task of the supply of construction materials is to ensure the supply of materials in sufficient quantity, synchronous in type, timely in time, and quality with the most reasonable cost[4].

The cost of a work construction is the total cost needed to build, renovate, or expand the work's technical equipment. The cost of work construction is the investment capital of the work, including:

- Investment capital for construction and installation (construction capital)

- Investment capital for purchasing machinery and equipment (capital and equipment)

- Investment capital for other basic construction.

Commonly, from the perspective of construction products themselves and the beneficiaries of construction products, the construction works' quality is assessed by the essential characteristics such as functionality, usability, compliance with standards technique, durability, reliability, aesthetics, safety in exploitation, use, economy and guarantee of timing (service time of the work). More broadly, the quality of construction works can and should be understood not only from the product itself and the beneficiaries of the construction product but also in the construction product's formulation process with related issues - other necessary.

Construction works must be scheduled before they are commenced construction, following the overall approved project schedule. For large-scale construction works with a long construction period, the work construction progress must be made for each period, month, quarter or year. The investor, construction contractor, supervision consultant and related parties are responsible for monitoring, supervising the construction progress and adjusting the progress in case the construction progress is in one. The number of phases is lengthened but should not affect the overall progress of the project. 
Tuan Anh Nguyen, and Toan Long Pham

\subsection{FACTORS AFFECTING CONSTRUCTION MANAGEMENT}

A construction firm's production capacity is the highest possible ability to produce real construction products in a unit of time (usually years) of that enterprise.

The production capacity of construction enterprises is the production capacity of construction machines, workers' teams and production lines. The production capacity and workers' group can be calculated in a kind or estimated value of construction works.

The determination of production capacity should be based on the volume of construction and installation work performed during the year under all construction contracts. Because construction firms can hire machines and workers to build, their production capacity and production capacity are hired.

The technical level of technology plays a crucial role in construction production and business are demonstrated through the following contents:

Factors affecting the direction of development and application Scientific and technological advances in construction production include:

- Economical;

- Technical characteristics of construction production;

- The economic and natural characteristics of the country;

- Construction missions.

- Orientations for the development and application of science and technology in construction production:

- Orientations for labour tools: in construction must step up the application of mechanization, step by step reasonably apply automation, focus on developing small mechanics for construction, combine sequential walkthrough and shortcuts in the development and application of construction techniques.

Labour is the most dynamic and revolutionary factor among the factors of the production process. The qualifications and awareness of employees will have a powerful impact on the business performance of construction enterprises. The level of labor determines product quality and labor productivity. If the employees have high professional qualifications, it will improve labor productivity and save labor costs. Conversely, if the skilled labor is not enough to complete the job, the job will not be completed on time, the lack of quality will jam all other jobs, the result will increase repair costs or waiting for costs. Recruiting and training a highly qualified and conscious workforce is crucial to help businesses improve labor efficiency and reduce business costs.

In the current harsh competitive environment, it is required that construction businesses have to maximize construction costs, so the level of organization and management in general dramatically affects the business performance of businesses. Depending on the enterprise's size and business lines, a simple, compact, and suitable organizational system is built. The right management system will be the basis for recruiting into management positions following industry requirements and facilitating the use and improvement of administrators' expertise.

Construction volume management must be performed according to the approved design volume, which will directly affect the construction management. Construction volume is calculated and confirmed between investors, construction contractors, supervision consultants by time or construction stage, and the approved design volume for construction - acceptance, and payment under the contract [7].

The quality of construction design is an essential activity, and today is considered a top task. The level of customer satisfaction depends entirely on the quality of the designs. In the construction industry, the design is of prime importance. It is impossible to execute a project according to an inadequate or faulty design. The wrong design creates poor quality construction and cannot be constructed if the design is inaccurate. Therefore, quality management in building design must be implemented strictly.

The State's mechanisms and policies have a growing influence on enterprises' operations. Direct impact on credit issues, antitrust, tax, remuneration, support, and environmental protection. These impacts can create opportunities or threats for construction businesses. Political stability is also a group of favorable factors that increase the country's competitiveness in general and of the business in particular.

Competitors are the most direct factor in a construction business's ability to win a bid. The quantity, as well as the competitiveness of competitors, determines the level of competition in bids. To win the bid, the bidder must surpass all competitors participating in the bid. That is to ensure their superior capabilities against current competitors with potential competitors. Therefore, understanding the competition has necessary implications for 
construction businesses. The competition level depends on the number of bidders participating in the competition, the industry's growth rate, diversification of competitors, and barriers to entry of competitors - new potential [8], [9], [10], [11].

The end product of the construction industry is often large, heavy, and expensive. It requires a large geographic area, and most of them are made according to the investor's request, making production activities less stable and mobile according to the territory. Understanding the construction site is not easy, so it can face some disadvantages that increase costs for businesses during the construction process.

\section{REALITY}

From 2010 to now, Vietnam's economy has been affected by the global economic downturn, and the construction industry is also suffering severe impacts. Many construction works were not continued; many construction companies fell into difficulties. However, in that context, Hoa Binh Construction Group had an entirely positive business result. Not only has the revenue continued to increase over the past five years, but the Group's profit has still ensured to increase with a large number and contributed significantly to the budget.

The above advantages have helped the Group achieve positive business results. Achieving today's results is a great effort, combining all the individualsin the Group.

\subsection{INTERNAL FACTORS}

The construction of the Company's works consists of many items, requiring the use of labor, materials, and special machines. Therefore, construction implementation met many difficulties and difficulties. The Group is forced to calculate the most effective implementation plans, carefully from survey to construction. The cost is always increased because the transportation of labor, materials, and machinery is more expensive than other constructions, not to mention overcoming geographical problems and natural disasters.

To create a product of the construction industry often takes a long time, consisting of many different stages. Depending on the project's size and nature, each technological stage is divided into many small phases. These small stages must be carried out in a precise quantity and technique to create the final product of good quality to meet the project's fundamental requirements.

The average number of devices in actual use compared to the total number of available devices is always at the highest level. For example, in concrete mixing plant, the number of times used compared to existing equipment always reaches $95 \%$ rate, which means that operating at maximum capacity is not wasted, or like cars, pumps machines Land leveling always has a high coefficient of use to meet the requirements. The number of equipment and machines is always used up to job requirements. For example, the self-propelled crane is always used all the time; no machine has much downtime. However, some computers are still due to the nature of their work and their functions, but the number of devices used in a short period should not be used too much. All kinds of machines' capacity are always high from $85-90 \%$ without being wasted during construction such as punching machine, table compactor with the capacity of $90 \%$. The Company's machinery and equipment always have a high coefficient of use. After all, the Company constructs many works simultaneously because most of them are modern machines, so the Company always operates at the highest capacity. Some devices are not idle much but put to use most of the time, thus creating high work efficiency.

Currently, Hoa Binh Construction Group has 3,795 management, an indirect team, 4,020 organic workers, and 21,100 subcontractors. With the current staff of employees, the Group always ensures that the Company can perform OK construction works[7].

\subsection{EXTERNAL FACTORS}

Operating in any industry also needs the general guidance of the State. The construction industry is no exception. All construction companies must comply with specific mechanisms and policies of the State, which are legal documents such as the Construction Law, Law. Bidding, Decrees, and other sub-law documents such as the Decree on raw material consumption are common grounds that the Company must comply. These legal documents create a similar competition mechanism for all companies in the market mechanism. Hoa Binh Construction Group 
is a part of the construction industry, so compliance with the above regulations is a right and a requirement for the Group.

Under the old mechanism, State-owned enterprises, including construction enterprises, all follow a unified topdown plan when carrying out production and business. These businesses do not have to worry about finding inputs, not having to worry about the market, finding customers, all provided by the State. It is these things that make businesses rely on, expect, and have no motivation to compete.

Hoa Binh Construction Group has to take care of everything, from searching for customers, input factors, potential markets ... and enhancing competitiveness. Most of the firms in the construction industry are large ones. These businesses belong to substantial construction corporations such as Coteccons, Ricans, An Phong, Central.

However, joining this industry also has specific barriers such as technology, scale, reputation, and brand name. Therefore, companies in the industry also have certain advantages, and if these advantages are well promoted, it is not easy for potential competitors to enter the market. However, the Group has always tried its best to improve management, especially its reputation and brand name, to become one of the big construction companies.

Inputs of the construction industry are diverse, from raw materials to machinery and equipment for construction. The current difficulty is that most modern machinery and equipment in the country are self-produced and mainly imported in other countries, specially developed technology countries such as Germany, France, Japan, and Italy. ... The import of many materials and equipment to serve the operation causes many difficulties for the construction industry of Vietnam in general and Hoa Binh Construction Group in particular and leads to the machinery's cost. Construction equipment increased.

Among the input factors, the value of raw materials accounts for the largest proportion of the project cost. Therefore, its fluctuation has a significant influence on the cost of the project. In recent years, due to the influence of the macroeconomic environment and inflation, commodities' prices have increased significantly, and construction materials are not out of that number.

Currently, the number of projects assigned to Hoa Binh Construction Group is quite large. Therefore, the works are spread across the North and South, and there are many works located in complicated geographical areas, difficult to construct, such as in mountainous, remote, and isolated areas. Difficulty in transporting raw materials and machines made costs soaring. The Company could not actively source inputs. Because the natural conditions are too complicated, when the architect designs the technical drawings, they have not considered all these possibilities, so many construction works are costing or prolonging the progress.

The quality of construction works: Hoa Binh Construction Group has always tried our best to create works of the best quality with the earliest completion time to hand over to investors and put the works. To use, bringing benefits to both the investor, the Group, and the whole society.

Regarding the management and use of machinery and equipment: The Group has also effectively used modern construction machinery and equipment, advanced construction solutions to improve further and further enhance the Group's competitiveness...

Human resource management: Hoa Binh Construction Group is always aware that excellent human resources management is one of the fundamental factors to complete construction work. The Company's human resource is always sufficient for the construction of the project; the Company has also proposed a suitable plan to build and train sufficient human resources in quantity and quality, building a management team. Experienced and capable of meeting the market and complicated developments with a team of skilled and professional technicians and many workers.

Regarding the management and use of materials: Hoa Binh Construction Group has always been conscious of managing and using materials economically. Raw materials are centrally managed and strictly controlled from the supply and use stages to reduce the consumption of raw materials, ensure the quality of the work, and reduce the rate of waste and scrap.

During the past time, Hoa Binh Construction Group has achieved many successes, especially in construction works. The Company has earned an excellent reputation in the construction market. However, like many other construction companies, there are still shortcomings that focus mainly on the following issues:

Regarding the management of machinery and equipment: Construction machinery and equipment are being used at full capacity, even in several projects, there is a shortage of machines. The mobilization of machinery and equipment still has many limitations. Some places are too many, some places are too few, and when needed, they do not have to rent, which causes much waste in the construction work. 
Human resource management: Labor use arrangement is not appropriate.

Materials management: Material management is still lax. In many projects, the workers used raw materials unreasonably and efficiently, the organization of norms, and the allocation of anti-theft supervision were not done well. In addition to the undeniable success that the Company has done, there are still some limitations affecting the efficiency of material cost savings, which are:

Construction quality management: Construction supervision has not been strict yet. At present, the Company still has many unsatisfactory construction quality works, such as prolonged construction progress and increased costs; some construction items that did not meet the quality as proposed. Out, leading to when the project is put into use, there are still complaints and complaints from customers [2].

\section{RECOMMENDED SOLUTIONS}

\section{Solution 1: Arranging the appropriate use of construction machinery and equipment on the site to use them more effectively}

Machinery and equipment have a direct influence on the performance of the construction team. The proper arrangement of machines and equipment will allow a close combination of labor and production materials to suit the company's production tasks, production scale, and production technology requirements identified to create the highest production efficiency. This is also an important content in production organization and construction team management. The machinery and equipment arrangement is considered reasonable when it ensures a balance: balance in the ratio between the capacity of machines capable of working, quantity, and quality of raw materials to be processed. That is to ensure the balance between the three factors of the production process. Thus, the rational arrangement of machinery and equipment will overcome the machine's interruption due to lack of equipment, sometimes excess machines in construction teams, sometimes in moderation, sometimes in haste, urgently cause waste of human and physical strength, affecting the quality and construction progress of works.

Currently, the use of machinery and equipment of Hoa Binh Construction Group is still ineffective, and there should be a plan to use specific machinery and equipment for each work item, each project.

At the Group, there are many types of machinery and equipment with diversified types and good quality. However, in the current production and business conditions with the number of projects spread across the country, machines' movement faces many difficulties, leading to a situation in which machines can be moved to buildings near the headquarters. Many, but at a different site, there is a lack of machinery. In some localities, the company chooses to hire machinery and equipment from other companies to serve its work, so it also affects quite a lot on cost, initiative, and quality of construction. On the other hand, an equally important subjective cause that significantly affects the efficiency of using machines and equipment is that the management of machinery and equipment is still weak.

The proper arrangement of machinery and equipment is first and foremost the Engineering - Equipment Department's responsibility, which currently manages most of the company's construction machinery. This department needs to develop a master construction machinery plan for each project and construction teams and teams, at least one month in advance of machine type, quantity, machine time, the gathering place of machinery and equipment. On that basis, I plan to move back and forth between works so that the most optimal. Subcontractors, construction teams can also base this plan of the factory to build their plans, creating an initiative in construction.

To implement the above solution and the human cost with the salary for the team of engineers to perform the work, the company needs a backup fund to quickly finance the machinery and equipment that the company short. This finance accounts for about $1 \%$ of the company's total revenue.

The machinery and equipment of the company must be arranged and used reasonably to avoid overlapping. If there is a situation where they cannot be used, they must be outsourced.

The company should also make specific plans for the machine transfer and document in the year's work plans to allocate the number of machines most effectively.

Construction progress is also a basis for machinery transfer. The progress needs to be urgently needed; the transfer also needs to correspond.

The company needs to make a specific plan, appoint qualified and experienced staff to learn, research, and arrange machinery and equipment to suit its conditions. 
Tuan Anh Nguyen, and Toan Long Pham

For long-term construction projects or many projects in a locality, the company should plan to transport machinery gathered to serve the company's construction and rent out machines during the construction periodidle time to increase sales. As for projects with short construction time, few projects in localities, you can choose to hire other companies in that locality to save costs.

\section{Solution 2: Choosing the appropriate form of organization, the production team}

The organization of working groups allows comparing the whole group's performance with each member's performance, thereby giving away to evaluate, find the causes and solutions to overcome weaknesses. In construction, the organization and production in teams are even more critical because the jobs in this industry require high labor productivity.

There are many forms of organization of production teams, namely:

- Specialized team: This is the consolidation of workers into one profession or a profession with different skill levels.

- General team: A combination of workers including many different professional occupations with the job structure compatible with the technical construction requirements to complete a combination of work, a work item, and construction work.

- Construction team: Organize work tasks with bear functions overall responsibility for the construction of an item, a project.

- Team framework: Teams only have the most superficial level of team leadership.

- Basic Human Resources Team: A team that maintains a core workforce if there is a lack of human resources, they should be coordinated or hired by their superiors.

- Teams with more or less fixed force: Teams that only exist in attack the process is extensive, with a continuous workload.

Depending on its characteristics of technology, human resources, etc., each company chooses a suitable form of the team.

At Hoa Binh Construction Group, the organization of labor is inadequate, leading to difficulties in management. To increase the efficiency of business operations, the company has minimized labor costs by forming frame teams when performing work on site. The establishment of a framework team brings many advantages when doing the job, such as Flexibility in workforce mobilization, there are no constraints on preferential allowances or insurance for workers ... That has reduced many costs when conducting construction works. Besides, the company also does not spend extra travel expenses of workers to works in different locations.

To overcome the above limitations in choosing the form of organizing the production team in each specific project, the company should consider its available conditions, the investor's requirements on progress. , the quality and the computational consideration of the volume of a particular type of work determines which form of production team organization should be appropriate.

For projects of great value and long construction time, investors require high quality and construction progress. The company should organize a specialized team. Because when organizing construction teams in a specialized team, they will best complete the jobs with high technical requirements and shorten construction time. With Hoa Binh Construction Group, the company often wins contracts for valuable and large-scale projects, setting up several specialized teams for essential jobs such as iron and waterproof teams. , finishing team ...

In order to implement the above solution, the company must first have a recruitment fee. Next is the cost of training and retraining for workers at the site or in training courses at vocational secondary schools.

To implement the above solution, the first thing needed is the human factor. The people here are recruiting officers. These people must be knowledgeable about each specific job to choose suitable candidates to participate in recruitment. Another indispensable factor is the finance for recruitment and training. The company should have a fund for this work and be directly managed by the chief administrative officer.

When the company implements these solutions, the company will reduce the downtime in construction. The company can even rent out machines in the absence of machinery. This can also be a source of additional revenue for the company. 


\section{Solution 3: Improve management, economical use of materials}

Each production and business enterprise has many different products and tends to diversify its products more and more. Producing each product requires a very diverse number of components, parts, and materials, many different types. Furthermore, materials need to be used at different times and often change. Especially for construction companies, the demand for raw materials is enormous. The proportion of materials accounts for $70 \%$ $-80 \%$. Therefore, the management and efficient use of raw materials is a prerequisite to lower costs, reduce costs, and improve the business's business efficiency. Planning the exact material needs, the right volume and the timing required is an essential basis for keeping stock stocks at a minimum, but it is not a simple matter. Stock management models are mainly about keeping stock levels stable without considering the interdependent relationship between building materials, which requires availability at other times. Together. This management often increases costs.

Although there have been many attempts to use materials efficiently and economically in the production process, the loss is inevitable. Besides, there are interruptions in construction due to the inadequate supply of materials or the improper supply of materials or the increased cost of materials and the cost of transporting materials.

In particular, the loss of raw materials makes the actual quantity of materials in the construction decrease, forcing many work items to reduce materials not as expected.

Building the MRP begins with the following end product production schedule that translates into a need for needed parts, details, and materials in different stages. The end product determines the expected need for lowerlevel parts and components depending on the product structure. MRP calculates the number of parts, parts in each stage for each product type in close relation to the available stock and determines when to issue an order or production order for each part that part.

The MRP seeks to identify the relationship between the production schedule, the order, and the volume of receipt and product demand. This relationship is analyzed from when a work item or work is constructed to the end of it.

To implement the above solution well, the company needs to make appropriate and reasonable investments due to such activities as propaganda, education on the sense of saving materials, training of materials management staff, training workers in the economical use of raw materials. Adequate and suitable material control and protection staff

are recruited. Besides, the company has to invest a certain amount of money in training highly qualified staff to plan materials for each item, each project. The Group also has to spend a certain amount of expenses to pay salaries, bonuses, allowances, and subsidies following these officers' regime. Another expense that should be noted is the costs of computers and facilities for material demand planners. The Finance - Accounting Department manages these expenses.

In order to implement this solution well, the human problem must be on top. We need three staff, one of whom is a bachelor of economics, two people are construction engineers with a deep understanding of building materials. The security guards team is people with transparent backgrounds who must be tasked with cross management most effectively.

To better serve the staff's planning, the company needs to equip computer systems, workplaces, and other necessary conditions such as construction documents, work items, and documents-materials about the supplier, price, quality, and type of materials needed.

An indispensable condition for material planning is the financial source for the above activities.

When implementing the above solution, the company is expected to reduce raw material inventories to below $10 \%$ of raw material value; reduce waiting time for the construction process to ensure the construction progress of work items, not let a project exceed the construction progress due to raw materials; create satisfaction and confidence for investors; create conditions for the departments to coordinate closely and unify with each other, promote the general construction ability of the company. Thanks to that, increasing the efficiency of production and business of the Group.

\section{Solution 4: Completing the construction supervision}

Construction supervision is the work of inspecting, urging, directing, and evaluating people participating in the work. Construction supervision is subject to construction work items, relevant laws, regulations, policies, and technical standards, written work contracts as the support, and real rules show work, use construction efficiency as purpose. Supervision is a crucial area because there are timely supervision and direction to avoid losses in 
construction. If the construction quality is not strictly monitored, the construction time is not on schedule, and if not monitored, the number of lost materials will be huge.

Hoa Binh Construction Group faces many construction work problems by the supervision not near from the beginning. Specifically[6]:

- Currently, the company still lacks a team of engineers to supervise both quantity and expertise.

- Almost all work items are done under the contracting mechanism. Small teams take on the responsibility of building construction for the company and only care about their construction. When there is no close supervision, the linkage between teams is not clear, work may overlap, or teams cause trouble for each other, affecting the overall construction quality.

- There is a situation of material loss or carelessness; the result is not achieved as the target set.

- The phenomenon of running according to the progress without ensuring the work's quality or ineffective plan arrangement makes the construction work delayed.

First of all, the company should focus on completing the critical points of construction supervision, including the main content of supervision, supervision order, supervision measures.

\section{Construction supervision content:}

- Help construction unit write construction commencement report.

- Verify the construction organization design, technical plans, construction plans, and schedules that the construction teams and teams have proposed, and provide comments simultaneously.

- Verifying the list of construction materials and equipment, standard specifications proposed by the construction agency.

- Urge and inspect the team to strictly comply with construction contracts and technical standards of works.

- Check the quality of materials, structures, and equipment used by the company, check the work of labor safety.

- Checking the construction progress and quality of construction and acceptance work items, sign payment vouchers.

- Organize the design unit and the construction team to accept the whole project, sign payment vouchers.

- Verification of works settlement.

\section{Build a regime of responsibility according to control goals:}

Develop a regime of responsibility based on quality control: divided into Three stages.

Construction preparation stage: materials are strictly checked at the site; materials that are not suitable for specified quality must require additional construction units to meet the required quantity and quality. Checking machinery and equipment, not allowing the use of equipment that does not meet the standards and regulations on technology, must add equipment that the quantity and production capacity are not enough to ensure progress and quality-the amount of work.

Construction stage: check the quality assurance system of the construction unit and bring into play its effects, check the work activities of the construction team, if detecting errors, have the right to issue decisions to repair or suspend construction.

Acceptance test: verify the diary of the works according to the quality assurance system. We are conducting the inspection of the product's internal quality and geometric dimensions, signing and receiving satisfactory products, approving the final acceptance results, and confirming responsibility for errors.

\section{Develop a regime of responsibility based on the control of the work progress}

- Planning and approval of work progress plans.

- Check the implementation of the progress. If teams' construction progress does not keep up with the planned schedule, they must instruct the team to find measures to catch up.

- The approved time is extended: if the team's delay is due to reasons other than the team itself, it will be based on a long contractual condition and be responsible for the team cost compensation. 


\section{Completing the Construction Management at Hoa Binh Construction Group}

\section{Build responsibility according to the control of cost.}

- Calculate the volume of completed teams based on the calculation results payment and vouchers, payment to the team.

- Adjusting prices based on market changes and contractual regulations, price adjustments for raw materials, labor and construction equipment.

In all cases, the supervision engineer must listen to the construction unit's opinion, comply with the construction management agency's instructions, promptly summarize lessons learned, and regularly improve the supervision level...

Scientifically organizing the construction supervision system creates conditions for businesses to grasp the actual situation at the site and make timely adjustments. Avoid wasting resources when things go wrong.

The supervision engineer strictly observes the order of supervision to control the construction order of the construction teams. Ensuring work progress, building quality, and controlling costs are very beneficial. The supervision order is divided into three distinct areas: supervision of construction quality, monitoring of construction progress, and monitoring of construction costs.

First of all, the company needs to have a precise regulation on the content of construction supervision, clearly defining the responsibilities of the construction party and the supervising party, specifying how to handle the trying to happen. It is necessary to strictly abide by the regulations, rules, standards, and laws of the state and locality. Must have a team of qualified supervision engineers. The company needs to have sufficient equipment for inspection and testing work testing and acceptance.

When applying this solution effectively, teams will be more closely monitored, reduce arbitrarily changing construction design processes, or cheat in the use of inputs to benefit. So many, so much. The construction and installation works of the teams have also been improved because they always receive the guidance of the process and rules of the company's supervising engineers.

\section{CONCLUSIONS}

Hoa Binh Construction Group is on the rise and has more fantastic opportunities, especially when Vietnam is a member of the World Trade Organization WTO. Nevertheless, besides the advantages, these events and the domestic business environment also give the company many challenges.

In the current trend of integration and globalization, competition in the market is becoming more and more fierce. More than ever, the company must always strive not only content with the results achieved but must take it as a solid premise for further determination in the marketplace. On the other hand, improving construction works' quality, lowering production costs, and ensuring construction progress is vital to construction businesses in general and Hoa Binh Construction Group.

When implementing the topic "Completing the work construction management," the author wishes that Hoa Binh Construction Group will achieve higher business efficiency, minimizing construction design errors. , the capacity of using machines and equipment has been improved, human resources are used effectively, using rationally and efficiently input materials, improving the efficiency of construction supervision ... contributing making the Group increasingly assertive on the path of integration, becoming one of the leading construction companies in Vietnam and gradually reaching regional and international markets.

Although this is not a new field, there are not many people participating in the research; On the other hand, due to market volatility and some other objective reasons, despite many difficulties in collecting documents, data ..., the author of the thesis still tries to complete the research. Simultaneously, they also boldly made opinions based on scientific research and seriously about the issue with the encouragement, encouragement, and help of instructors, family, and colleagues. Through research, the author of the essay would like to draw some conclusions as follows:

1) Improving construction management is an urgent job, not only in the present time, in the future, but also fundamentally changing the perception of construction management before of both customers and suppliers. From an objective view, we can see that our country's construction management work is still low, the cause of the problem is that we are still weak in the management of materials and machinery. Construction equipment, labor management, capital management. Therefore, completing construction management is an extremely urgent job and necessary. 
2) Completing construction management is an objective requirement of the renovation process, moving from the old management mechanism to the new one, especially in the current economy's opening and integration period. Many factors influence many groups of factors such as State policy mechanisms, competitors, construction management skills, skills and awareness of workers, quality of the survey, and design. ... The study of these factors is also one of the views that the essay mentions.

3) Construction management of Hoa Binh Construction Group, according to the author's assessment, still has shortcomings in general. This conclusion is reviewed and drawn from the situation analysis, public documents, reports. The cause of this situation is many, but emerging is that the supervision of construction is not yet strict, the management of labor and wages is not appropriate, construction machinery and equipment have not been used. Maximum capacity, loose material management, leading to slow construction progress, affecting the project's quality. That is also the basis for proposing solutions to improve the construction management of the author.

4) The author of the thesis also presented the development directions and goals of the company, especially in construction work from now to the year 2040. On that basis, the essay proposed four essential solutions and two essential recommendations for State management agencies to improve construction management at Hoa Binh Construction Group in the coming time.

\section{RECOMMENDATIONS}

First, there are many shortcomings in construction investment management construction in general and capital construction investment. This leads to a lot of the project made mistake with the estimate, did not strictly manage the budget, the design was not reasonable with each locality's conditions, the planning was not synchronous, causing difficulties for the construction units. Construction investment authorities need to have a master planning policy, on that basis, conduct a public and transparent tender of projects to ensure the best contractor to execute. Submit. This will help companies like Hoa Binh Construction Group have the opportunity to play their strengths fully and have the motivation to improve their competitiveness.

Second, at present, construction enterprises are not allowed to increase selling prices to control inflation, but not to lose money, still have to ensure production and business plans while production costs continue to increase prices while The bank's lending rate is still relatively high, input material prices also increase. Therefore, State management agencies should have appropriate policies to issue a list of raw materials, fuels, and construction materials that are allowed to adjust prices, calculate additional construction costs, and have the authority to decide. Determine the adjustment of cost estimates, bidding package prices, total investment, contracts, contract advance, and temporary payment of additional construction costs due to price fluctuations. Primarily, it is necessary to clarify the concept of "price volatility" and the apparent decentralization of powers and responsibilities of the investor in handling price issues and contract form soon. Besides, the promulgation of price mechanisms when changing project groups according to size, avoiding price fluctuations, is that both construction investors and contractors are "immobile," leading to handover of works is slow or works of low quality.

\section{SOURCES OF FUNDING}

This research received no specific grant from any funding agency in the public, commercial, or not-for-profit sectors.

\section{CONFLICT OF INTEREST}

The author have declared that no competing interests exist.

\section{ACKNOWLEDGMENT}

None. 


\section{REFERENCES}

[1] Nguyen Dinh Tham, Nguyen Ngoc Thanh (2001), Planning, Organizing and Directing Construction, Science and Technology Publishing House, Hanoi.

[2] Decree No. 46/2015/ND-CP dated 12/5/2015 of the Government on quality control and construction maintenance.

[3] Decree No. 59/2015/TT-BXD dated 18/06/2015 of the Ministry of Construction on management of construction investment projects.

[4] Decree No. 32/2015/ND-CP dated 25/3/2015 of the Government on management of construction investment costs.

[5] Construction magazine of 2009, 2010, 2011, 2012.

[6] Documents reported by departments of the Hoa Binh Construction Group.

[7] Le Quang Long. Complete the selection of construction contractors at the Construction Investment Management Board of Tan Binh District, Ho Chi Minh City. Specialization in Civil Engineering and Industrial Construction, City University of Technology. HCM City, 2019.

[8] Tuan Anh Nguyen, Hai Van Bui, 2021, Determination of Factors Affecting Capabilities of Competitiveness in Construction Auction of Company 59 - Ministry of Defense, INTERNATIONAL JOURNAL OF ENGINEERING RESEARCH \& TECHNOLOGY (IJERT) Volume 10, Issue 01 (January 2021),

[9] Ayodeji E. Oke et al. Assessment of Qualitative Factors Influencing Contractors Tender and Project Success in an Emerging Economy. 53rd ASC Annual International Conference Proceedings, 2017.

[10] Beltrán Aznar et al. Factors Affecting Contractor's Bidding Success for International Infrastructure Projects in Australia, Journal of Civil Engineering and Management, Volume 23(7) 880-889, 2017.

[11] Tolulope Samuel Fawale và Joshua Oluwasuji Dada. Impact of Contractors' Bidding Strategies on Bid Success in the Nigeria Construction Industry. International Journal of Built Environment and Sustainability, DOI: 10.11113/ijbes. v4.n1.156, 2018.

[12] https://hbcg.vn. 